\title{
The Effect of Perceived Image and Customer Experience to the Customer Value, Trust and Behavior Intention at Star Hotel in Makassar
}

\author{
Syahruddin* \\ *Lecturer
}

\begin{abstract}
The objective of this research were to find out and analyzed the effect of perceived image and customer experience to the customer value, trust, and behavior intention at star hotel in Makassar. The approach of this research was quantitative approach. This type of research was survey. The population was all customers at star hotel in Makassar that have operated at least the last 3 years (2013 up to 2015). Sampling technique used this research was purposive sampling by using cross section technique and estimation of Maximum Likehood $(M L)$ with 170 respondents. The data analysis is done with using Structural Equation Modeling (SEM). The result analysis shows that perceived image and customer experience gives positive effect and significance to the customer value, trust and behavior intention at star hotel in Makassar.
\end{abstract}

Keywords: Perceived Image, Customer Experience, Customer Value, Trust and Behavior Intention

\section{A. Background}

\section{Introduction}

Makassar has developing and promising business; one of them is hospitality aspect. This can be seen from the increasing of rooms in star hotels and homestay level. The development of hotel business causes a high level of competition hotel. But for a number of hotel entrepreneurs, that condition is not a major concern as long as the markets share still available. The hotels manager must try as best as possible in utilizing the existing gives the image of hotel and special services to the guests. Star hotel needs still relatively high following a number national and international activity that chose this city as the location of the event organizer. In 2013, rooms' hotel in Makassar grows 20 percent, to the planned three star hotel with 1.000 rooms will be built lately. Hotel and restaurant business that join in tourism sector have capability of being the second largest contributor after levy vehicles for Local Revenue of Makassar during the first quarter this year recorded Rp. 74 billion. Generally South Sulawesi still requires additional around 5.000 rooms' hotel up to 2013 to support the growth of occupancy rates that still increase.

The growth and development of the hospitality industry in Makassar from year to year showed a rapid increase. As a fast growing industry, intense competition among fellow hotel in Makassar raises a fairly strong competition, any hotel that wants to generate a positive perceptions or good image in community then that hotel should assure customers that their hotel is more superior to others. To make the hotel could defend and protect the image of the hotel should be able to provide and pay attention to all the customer needs, this can affect the old hotel to remain faithful and loyal to the hotels' customer. The developments of industry that grow rapidly bring implication to the competition between companies in that industry. In that situation, every company demanded to hold out and increase the income in order to be success in crisis era although in hard competition.

Association of Hotel and Restaurant Indonesia argued that 31 hotels opened in Makassar, South Sulawesi as long 2014. With the hotel opening, number of rooms increased by 5.125. Means the number of rooms in 2014 increased by 64,8 percent over the previous year, 7911 rooms (http://www.tempo.co, Tanggal 24 Maret 2014). While the hotel occupancy rate in Makassar in 2013 to an average of 69.74 percent. This is lower than the occupancy rate in 2012 averaging 72, 59 percent. The decreasing of occupancy hotel caused by the rapidly hotels development in Makassar. Therefore, PHRI of South Sulawesi at the end of last January insisted the government to make a moratorium to suppress the growth of hotels in Makassar. (http://www.tempo.co, Tanggal 24 Maret 2014). The increasing of hotel in Makassar resulted in intense competition in the hotel industry of Makassar city. Hotel parties race to improve competitiveness and the image of the hotel by always creating a differentiation for their business to retain more customers in order to increase the hotel revenue.

The higher growth of the hotel resulting decline in occupancy rates, it is also impact on the decline of hotel revenue. It is known that the income from hotel occupancy rate is the main factor of hotel revenue. With this condition it should increase hotel revenue by seeking service maximize to the customers. One of the important factors in doing maximize service to the customer is how the company give service as maximize as possible to make the customer satisfied. Yamit (2003), argued that customer satisfaction is determined by the quality of service in the field of phenomenon. If the service is not the same or not in accordance with the 
customer's expectations, for customers, service that provided rated ugly and unsatisfactory. Customer satisfaction according to Barkelay and Saylor (1994) is focused on management process that oriented to the consumer, even stated that customer satisfaction is the quality. Make customers loyal and satisfied with the service performed by the company, particularly in the hospitality services is not enough, the company must establish a consumer to have a strong desire to be loyal to a product or service.

According to Yun and Baik in Hsu, dkk (2009) Behavioral intention refers to the conscious of someone level effort will deploy to conduct and behavior can be measured by word of mouth, to switch stores, and future patronage. Customer satisfaction is the core to store the loyalty and behavioral intention. According to Zeithaml (2003), behavioral intention can be seen as an indicator that situation where a customer would remain a customer or leaves the company that had served him.

\section{B. Problem Statements}

Starts from a background that described to be essence problem in this research can be formulated as follows:

1. Whether perceived image effect to the customer value?

2. Whether customer experience effect to the customer value?

3. Whether perceived image effect to the trust?

4. Whether customer experience effect to the trust?

5. Whether perceived image effect to the behavior intention?

6. Whether customer experience effect to the behavior intention?

7. Whether customer value effect to the behavior intention?

8. Whether trust effect to the behavior intention?

\section{Objective of the Research}

Relating to the problem statements, the objective of the research as follows:

1. To analyze the effect of perceived image to the customer value.

2. To analyze the effect of customer experience to the customer value.

3. To analyze the effect perceived image to the trust.

4. To analyze the effect of customer experience to the trust.

5. To analyze the effect of perceived image to the behavior intention.

6. To analyze the effect of customer experience to the behavior intention.

7. To analyze the effect of customer value to the behavioral intention.

8. To analyze the effect of trust to the behavioral intention.

\section{Significance of the Research}

This research is expected to give contribution as follows:

1. Contribute to the management department, especially marketing management.

2. Contribute to the study marketing management especially empirically testing.

3. Contribute to the future research agenda on theoretical model which is generally has not been tested empirically.

4. Contribute to the hotel manager especially to use factors that effected customer value, trust and behavioral intention.

5. Contribute to the preparation of strategic planning in facing competition in the hospitality industry and also to set various operational policies relating to the hotel customer service.

\section{A. Theoretical Review of Perceived Image}

\section{Review Of Related Literature}

According to Aaker in (Simamora, 2003: 281), perceived quality based on consumer subjective thought. In perceived quality contained conviction to the brand performance. Consumer perception the quality is overall consumer assessment to the product performance or service (ferrinadewi, 2008:61). In applying assessment to the product performance, consumer ability to assess depend on whether intrinsic attributes product can be perceived and evaluated to the consumer limited purchases caused by limited knowledge about manufacture product or even from consumer itself that has not enough time to do assessment. The consequence is consumer refer to relying on extrinsic attributes such as brand name, store name and price in evaluating quality product. The extrinsic attribute of this product acts a shortcut that provides some information to the consumer to do an evaluation.

Brand image is representation and whole perception to the brand that formed and information and experience from the brand. Image of the brand is related to the behavior such conviction and preference to the brand. Consumer that has positive image to the brand, possible makes a purchasing. 


\section{B. Theoretical Review of Customer Experience}

According to Gentile, Spiller, and Noci (2007), assumption of customer experience, defined that derived from a set interaction between customer and product, company or the majority of organizations that causes a reaction. This is personally experience and implying customer engagement to the different levels (either rationally, emotional, sensory, physical, or spiritual). According to Meyer and Schewager (2007), customer experience is customer feedback internally and subjective as a result of interaction directly nor indirectly to the company.

\section{Theoretical Review of Customer Value}

Monroe (1990) argued that customer value is tradeoff between customer perceptions to the quality or product benefits and sacrifice that done by paid price. Anderson, et al (1993) said that customer value is perceived worth a monetary unit to the economies benefits series, technical, service, and social as change of paid price to a product by consider offers and prices from available suppliers.

\section{Theoretical Review of Trust}

Trust is a business foundation. A business transaction between two parties or more will occur if there is mutual trust. Trust is not just recognized by business partner, but must be built at the beginning and can be evidenced. Trust has been considered as catalytic in some transactions between seller and buyer to the customer satisfaction can be realized as expected (Yousafzai et al, 2003).

\section{E. Theoretical Review of Behavior Intention}

Behavior Intention defined by Mowen and Minor (2002) as consumer desire to behave based on certain way in order to have, throw, using product or service. So consumer can show desire to get information, inform others about the experience to the product, buying product or certain service, or waste product with a certain way.

\section{F. Conceptual Framework}

Tang (2007) argued that corporate image admitted as function from accumulated purchase experience of consumption and has two main components: functional and emotional. Functional component related to the real attribute that easy to measured, while emotional component related to psychological dimension that created by feeling and attitude to organization. Feeling comes from individual experience with organization and from information processing about attribute that also functional indicator of company description.

The perceived image of hospitality will be worth to the client side if has strong emotional bond. As affirmed Butz \& Goodstein (1996) customer value is emotional bonds that exist between customers and manufactures after customers using product or service that resulting by supplier and get the product that provide additional value. In making trust to the perceived image, customer believes that operation of service providers can be believed and give value or rewards based on his sacrifice. Based on this opinion, image related to attitude such as conviction and preference business relation to an organization/ company. Gronross in Tjiptono (2000), explained that corporate image is profile, reputation, public image, and company attractiveness. This criterion is image-related criteria.

A company image can become extrinsic information and hint for the buyers either has potential and maybe or cannot be affect customer loyalty (example readiness to give positive word by mouth). Yun and Baik in Hsu, dkk (2009) state that Behavioral intention refers to someone conscious effort level will rally to do behavior and can be measured from word by mouth, to switch store, and future patronage. Therefore, there is relationship between company image and Behavioral intention.

According to Gentile, Spiller, and noci (2007), that Customer Experience defined a set interaction between customer and product, company, or part from organization that cause a reaction. This experience really personal and imply the customer involvement in different levels (either rationally, emotional, sensory, physical, or spiritual). From Sweeny dkk in Tjiptono (2005), one of dimension from customer value is emotional value. It is utilities that comes from feeling or affective/ positive emotions that inflicted by consuming product.

According to Moorman (1993), trust as individual willingness in drape him to other that involved in exchange because of individual has confidence to other side. When a party has confidence to other in exchanging and get reliability and integrity, it will be a trust. In this case to make consumer trust needs experience from the customer in consume/ use product/ service from a company.

Woman and Minor (2002) said that behavioral intention is a consumer desire to behave in a certain way in order to have, discard, using product or service. So consumer can make a will to get information, inform others about experience with a product, buying a certain product or service, or discard product with certain way. According to Seddon \& Sant (2007), effective management will become a customer experience in all touch points, is a key to make customer commitment, retention, and sustained financial success. 
The completely relation between variable explained in Picture 1 below:

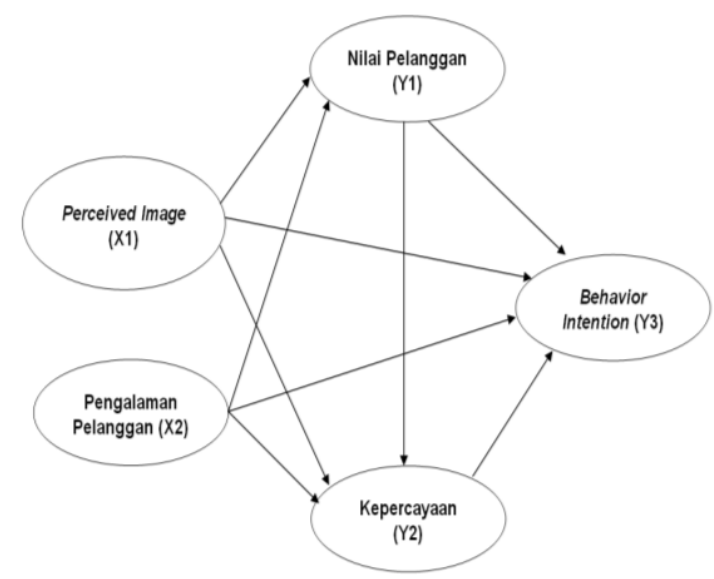

Picture1. Conceptual Framework

\section{G. Hypothesis}

Based on problem statement and theories above, the hypothesis formulated in this research as follows:

1. Perceived image effect to the customer value

2. Customer experience effect to the customer value

3. Perceived image effect to the trust

4. Customer experience effect to trust

5. Perceived image effect to the behavior intention

6. Customer experience effect to behavior intention

7. Customer experience effect to behavior intention

8. Trust effect to the behavior intention

\section{Research Method}

This research approach used quantitative approach. The type of this research is survey. The data collection of this research has done from December 2014 up to February 2015. This research conducted in Makassar, precisely some star hotels. The instrument that used in this research which serves as tool to collect the data was questionnaire. Scale that used in the questionnaire was Likert. The population of this research was all the customers at star hotels in Makassar that operated at least 3 years (2013 up to 2015). Sampling technique of this research was purposive sampling by using cross section technique. The criteria of sample that used was as follows: (1) consumers that have stayed minimum 2 days, and (2) consumers that have used hotels service previously. To got a sample that can be represent population, as alternative in determine research sample used frmula number of samples minimum from structural Equation Modeling analysis. According to Ferdinand (2002), Ghazali (2004), Ghazali (2008), Solimun dan Ronaldo (2009), sample size between 100-200 sample that can be recommended to estimation maximum Likehood (ML). Estimation model used maximum Likehood (ML), necessary data minimum 100 sample. According to Ferdinand (2002) SEM analysis needs sample at least 5 times indicator variables or estimated parameter that used Ferdinand (2002) also Solimun and Rinaldo (2009) give determination guidance of size sample same as 5-10 times manifest variable from overall latent variable. This research used 5 manifest variable and 26 indicators so total of latent variable is 31 latent variables. Based on sample determination criteria $31 \mathrm{X} 5=155$ sample and rounded to 170 samples. The instrument of data collection that used in this research were primary and secondary data, method of data collection used (1) questionnaire, (2) observation, observe directly to the company that become a sample, (3) documentation technique, and (4) deep interview. Technique of data analysis used analysis statistic descriptive analysis and Structural Equation Modeling (SEM) analysis also validity reliability data. Operational definition used to avoid double interpretation which is giving limitation to the variables that used in this research such: (1) perceived image (X1) defined as impression got by knowledge and someone experience about something. (2) customer experience (X2) defined customer feedback internally and subjective as result from directly interaction or indirect to the hotel side, (3) customer value (Y1) defined as suitability value that perceived by hotel consumer between service and hotel product with quality service and hotel product that accepted by customer, (4) trust (Y2) defined as customer desire in getting treatment from hotel side with expectation that the hotel side did important action to fulfill that expectation, apart from the ability, to monitor and control customer, (5) behavioral intentions (Y3) defined as customer expectation to be loyal in one product or service, repurchase in one product or service, and inform others about that experience with a product or service. 


\section{A. General Description of Research Objective}

\section{General Description, Findings And Discussion}

The object of the research was hotel star 3 in the administrative region of Makassar. Based on SK Menparpostel Nomor KM94/ HK103/mppt 1987, hotel is accommodation that uses a part or all building to provide specially services, food and drink and other general service that manageable commercial. Another sense of hotel is business services that concentrated to tenant room for inhabited in certain period, those rooms are designed complete with bathroom, and bedroom (Lubis, 2002). The meaning of star hotel refers to the term star hotel itself. Star hotel or hotel star is one of hotel classification. Hotel classification started from one star hotel up to five star hotels. The more stars the hotels have indicate the more complete amenities those hotels. According hotel Kepmen nexus No. PM. 10/PW.301/Pdb-77 in determining star of hotel based on regulation as follows; (1) the rooms of the hotel; (2) the shape of the hotel building; (3) equipment or hotel facilities; (4) quality service of the hotel. The classification of hotel star three has at least 30 rooms, three suite room, and restaurant. Ministerial decree above refined by KepMenbudpar No KM03/HK.001/MKP.02 which reads classification process of star hotel in Indonesia done by PHRI or Association of Hotel Indonesia. In previous ministerial decree, the quality service of hotel is the last thing in determining star of the hotel, and then the new regulation mentioned that service quality is main criteria in classification. The minister regulation in 2002, the term Hotel Bintang and Hotel Melati. Star (1 up to 5) will be given certificate that signed by head of central leadership PHRI and governor, while Melati certificate of Melati is taking care by PHRI province (regional leaders of agency).

\section{B. Findings}

Based on result analysis structural equation modeling that has got goodness of fit criteria, then tested significance of functional relationship between variable as in appendix. To ease in analyze functional relationship between variable and coefficient arranged in Table 1 as follow.

Table1. Effect between variables

\begin{tabular}{|l|l|l|l|l|l|}
\hline Variabel Eksogen & \multicolumn{2}{|l|}{ Variabel Endogen } & Estimasi & T Value & Prob \\
\hline \multirow{3}{*}{ Perceived image (X1) } & 1 & Nilai pelanggan (Y1) & 0.113 & 3.387 & 0.000 \\
\cline { 2 - 6 } & 2 & Kepercayaan (Y2) & 0.347 & 4.246 & 0.000 \\
\cline { 2 - 6 } & 3 & Behavior intentions (Y3) & 0.191 & 3.163 & 0.002 \\
\hline \multirow{3}{*}{ Pengalaman pelanggan (X2) } & 1 & Nilai pelanggan (Y1) & 0.132 & 3.933 & 0.000 \\
\cline { 2 - 6 } & 2 & Kepercayaan (Y2) & 0.361 & 4.439 & 0.000 \\
\cline { 2 - 6 } & 3 & Behavior intentions (Y3) & 0.173 & 2.929 & 0.003 \\
\hline \multirow{2}{*}{ Nilai pelanggan (Y1) } & 1 & Kepercayaan (Y2) & 1.225 & 4.874 & 0.000 \\
\cline { 2 - 6 } & 2 & Behavior intentions (Y3) & 0.374 & 2.202 & 0.028 \\
\hline Kepercayaan (Y2) & 1 & Behavior intentions (Y3) & 0.351 & 5.543 & 0.000 \\
\hline
\end{tabular}

\section{The Effect of Perceived Image (X1) to the Customer Value (Y1)}

Coefficient effect of variable perceived image (X1) to the customer value was $0.113(\mathrm{Y} 1)$ with $\mathrm{t}$ value 3.387 at significance level 0.000 . That coefficient showed that variable of perceived image (X1) showed positive effect on customer value (X1). This means that the increasing of perceived image (X1) followed by the increase of customer value (Y1) with assumption factors that affect the customer value (Y1) it's consider constant. Statistic value of t-hitung affect perceived image (X1) to the customer value (Y1) 3.387 with significance 0.000 or under 0.05 . This meant that perceived image (X1) gives positive effect and significance to the customer value (Y1).

\section{The Effect of Perceived Image (X1) to the Trust (Y2)}

Coefficient effect of variable perceived image (X1) to the trust (Y2) was 0.347 with $\mathrm{t}$ value 4.246 at significance 0.000 . That coefficient showed that perceived image variable (X1) showed positive effect to the trust (Y2). This meant that perceived image (X1) followed by trust increase (Y2) with assumption other factors that affect trust itself (Y2) that consider constant. Statistic value t hitung effect perceived image (X1) to the trust (Y2) 4. 246 with significance 0.000 or under 0,05 . This meant that perceived image (X1) showed positive effect and significance to the trust (Y2).

\section{The Effect of Perceived Image (X1) to the Behavior Intentions (Y3)}

The coefficient effect of variable perceived image (X1) to the behavior intentions (Y3) was 0.191 with t 3.163 at 0.002 significance. That coefficient showed that variable perceived image (X1) effect positive to the behavior intentions (Y3). This meant that the increase of perceived image (X1), followed by the increase of behavior intentions (Y3) with assumption of other factors that affect behavior intentions (Y3) was constant. Statistic thitung effect of perceived image (X1) to the behavior intentions (Y3) was 3.163 with significant 0.002 or under 0.05 . This meant perceived image (X1) affect positively and significant to the behavior intention (Y3). 


\section{The Effect of Customer (X2) $t$ the Customer Value (Y1)}

The coefficient effect of variable customer experience (X2) to the customer value (Y1) was 0.132 with t 3.933 at significant standard 0.000 . That coefficient showed that customer experience (X2) positively affected to the customer value (Y1). This mean that he increase of customer experience (X2), followed by the increase of customer value (Y1) by assumption other factors that affected customer value (Y1) by mean constant. Statistic $\mathrm{t}$ hitung effect of customer experience (X2) to the customer value (Y1) was 3.933 with significant 0.000 or under 0.05 . This meant customer experience (X2) effected positively and significant to the customer value (Y1).

\section{The Effect of Customer Experience (X2) to the Trust (Y2)}

The coefficient effect of variable customer experience (X2) to the trust (Y2) was 0.361 with t value 4.439 at significant standard 0.000 . That coefficient showed that variable customer experience (X2) effect positively to the trust (Y2). This meant that the increase of customer experience (X2), followed with trust increasing (Y2) with assumption other factors that effect to the trust (Y2) that affected trust itself was constant. Statistic value thitung effect customer experience (X2) to the trust (Y2) was 4.439 with significant 0.000 or under 0.05 . This meant that customer experience ()X2 positively affected and significant to the trust.

\section{The Effect of Customer Experience (X2) to the Behavior Intentions (Y3)}

The coefficient effect of customer experience (X2) to the behavior Intentions (Y3) was 0.17 with $\mathrm{t}$ value 2.929 at significance standard 0.003 . That coefficient showed that variable customer experience (X2) effect positively to the behavior intentions (Y3). This meant that the increase of customer experience (X2), followed the increase of behavior intentions (Y3) with assumption other factors that effect to the behavior intentions itself was constant. Statistic value of t hitung affected customer experience (X2) to the behavior intentions (Y3) was 2.929 with significant 0.003 or under 0.05 . This meant that customer experience (X2) affected positively and significant to the behavior intention (Y3).

\section{The Effect of Customer Value (Y1) to the trust (Y2)}

The coefficient effect of customer value (Y1) to the trust (Y2) was 1.225 with $\mathrm{t}$ value was 4.874 at significance standard 0.000 . The coefficient showed that variable costumer value (Y1) effect positively to the trust (Y2). This meant that the increase of costumer value (Y1), followed by the increase of trust (Y2) with assumption other factors followed a trust $(\mathrm{Y})$ was constant. Statistic value effect customer value (Y1) to the trust (Y2) was 4.874 with significance 0.000 or under 0.05 . this meant that customer value (Y1) effect positively and significance to the trust.

\section{The Effect of Customer Value (Y1) to the Behavior Intentions (Y3)}

Coefficient effect of variable customer value (Y1) to the behavior intentions (Y3) was 0.374 with $\mathrm{t}$ nilai 2.202 at significance standard 0.028 . that coefficient showed that variable customer value (Y1) effect positively to the behavior intentions (Y3). This meant that the increase of customer experience (Y1), followed by the increase of behavior intentions (Y3) with assumptions other factors that effect of behavioral intentions (Y3)was constant. Statistic value of thitung effect to customer value (Y1) ti the behavioral intentions (Y3) was 2.202 with significance 0.028 or under 0.05 . This meant customer value (Y1) effect positively and significant to the behavioral intentions (Y3).

\section{The Effect of Trust (Y2) to the Behavioral Intentions (Y3)}

Coefficient effect of variable trust (Y2) to the behavioral intentions (Y3) was 0.351 with value 5.543 at significant standard 0.000 . That coefficient showed that variable trust (Y2) affected positively behavioral intentions ( $\mathrm{Y} 3$ ). This meant that the effect of increase of trust (Y2), followed by the increase of behavior intentions (Y3) with assumptions other factors that affect behavior itself (Y3) was constant. Statistic value $t$ hitung affected trust (Y2) to the behavior intentions (Y3) was 5.543 with significant 0.000 or under 0.05 . This meant trust (Y2) effected positively and significant to the behavior intentions (Y3).

\section{Discussion}

1. The Effect of Perceived Image to the Customer Value

The effect of perceived image to the customer value is positive. This means that the increase of perceived image will followed by the improvement of customer value with assumptions other factors that affect the size of perceive image is considered constant.

The perceive image of hospitality would be worth on the customer side if they have strong emotional bond. This based on Butz \& Goodstein (1996) that customer value is emotional bond that exist between costumers and manufacturers as customers use the products or services produced by supplier and found that the product concerned provide additional value. 
This research result shows that perceived image significantly effects to the customer value, this result based on research feom Solechan and Euis Soliha (2015), from their research concluded that there is positive effect and significant between image and customer value. The result of this research according to the findings of research conducted by Mohammad Rezah Hamidizadeh, Nasrin Jazani, Abbasali Hajikarimi, Abolghasem Ebrahimi (2011) find that image effect positive on customer value. Beside that research of Eggert Andreas and Ulaga (2002) about Customer perceived value said that customer value that superior in positioning excellence. Where customer value affects positive to the image.

\section{The Effect of Customer Experience to the Customer Value}

The effect of variable customer experience to the customer value is positive, this means that the increase of customer experience followed by improvement of customer value with assumptions other factors that affect the size of customer experience is considered constant. According to Sanchez (2006) one of dimension customer value is the functional value, defined as perceived usefulness of the product and service attributes. Functional value in the form of benefits perceived by customers given by employees, perceived benefits by customer derived from the quality of services provided and perceived benefits of the level costs incurred by the customer.

The result of this research indicate that customer experience to the customer value, this result could be compatible with research of Shilpa Iyanna, Carmela Bosangit and Amrul Asraf Muhd-Any. (2012). By thi research concluded that customer experience affects to the customer value.

\section{The Effect of Perceived Image to the Trust}

The effect of perceived image to the trust is positive. This means that the increase of perceived image followed improvement trust with assumption other factors that affect the size of perceived image is considered constant. In making confidence in perceived image, customers believe that the operations of service providers can be trusted and given rewards in accordance with sacrifice. Based on this opinion, image related to attitude that belief and preferences of the business relationship to the organization/ company. Gronross in Tjiptono (2002), explained that corporate image is profile, reputation, public image, and attractiveness of a company. This criterion is image- related criteria. Murthy in Kartajaya (2004:156), also express that a brand image is symbol of trust. Brand value also determines the confidence, where the value is perceived as positive and capable of creating trust.

The result of this research show the effect of perceived image to the trust, this result could be compatible with research of Merza Ariszani, Suharyono and Srikandi Kumadji. (2015). The result of this research is known that variable image significant effect to trust variable. This research also compatible with research that done by Khalil (2013) that company with good image capable to find the customer trust and purchasing interest for product and services, this shows that company image in consumers' mind can cause consumer confidence.

\section{The Effect of Customer Experience to the Trust}

The effect of customer experience to the trust is positive. This means that the increase of customer experience will followed by the improvement of trust with assumptions other factors that affect the size of perceive image is considered constant. According to Mayer et al. (1995) factors that shape a person's belief against another is ability. Ability refers to competence and seller/ organization characteristic in affecting and authorizes specific area. In this case, how the seller is able to provide, service, and securing the transactions of the other interference. This means that, obtain consumer satisfaction and security guarantees from the seller in the transaction. Kim et al (2003) said that ability covered competency, experience, attestation intuitional, and knowledge capability.

The result of this research indicate that the effect of customer experience to trust, this research also compatible with research that done by Triyani Rahmadewi, Naili Farida and Reni Shinta Dewi, (2015). From the result of this research shows that customer experience effect to the brand trust, a good customer experience directly make a customer confidence is increased because of evidence gained from experience.

\section{The Effect of Perceived Image to the Behavioral Intentions}

The effect of perceived image to the behavior intentions was positive. This means that the increase of perceived image will be followed by the improvement behavior intentions with assumption other factors that affects the size of perceive image is considered constant. The result of this research showed that perceive image significantly affected to the behavior intentions, this result compatible with research of Chung-Wei Kuo and Mei-Ling Tang (2011). This study provides empirical evidence to demonstrate the quality of the environment accessible not only affect the quality efesiense, but also company image. The result provides valuable reference for managing critical person on the use of parents. 
Company image can be extrinsic information guidance for good buyers and potential and maybe or cannot affect customer loyalty (such as willingness to provide good word by mouth to mouth). As Yun and Baik in Hsu, dkk (2009) argue that Behavioral intention refer to someone effort that exerts a conscious level to perform the behavior and measured with word of mouth, switch store and future patronage. Therefore, there is a linkage between company image and Behavioral Intention.

\section{The Effect of Customer Experience to the Behavioral Intentions}

The effect of customer experience to the behavior intentions was positive. This meant that the increase of customer experience was followed by the improvement of behavior intentions with assumption other factors that affect the size of customer experience was considered constant.

The result of this research showed that customer experience affect significant to the behavior intentions, this result compatible with research from Beatriz Moliner et al, (2010). The research result shows that variables below has significant effect to the intentions: complain attitude, information level and complain experience, dissatisfaction level and possible success by complain. The effect of attitude increase to complain has founded in customer with previous customer.

Mowen and Minor (2002) said that behavioral intention is customer desire to behave based on certain way to have, discard, use product or service. So consumer can be intend to find out information, tell others about experience with a product, buying product or certain service, or discard product with certain way. According to Seddon \& Sant (2007) effective management to the customer experience to the all touch points, is a key to establish customer commitment, retention, sustainable of financial success.

\section{The Effect of Customer Value to the Behavioral Intentions}

The effect of customer value to the behavior intentions was positive. This meant that the increase of customer value was followed by the improvement of behavior intentions with assumptions other factors that affect to the size of customer value is considered constant. According to Zeithaml (2003), behavior intention can be seen as indicator who gives situation sign where a customer stay become a customer or leave the company that serve them lately. Behavior intention is divided into two namely: favorable intention and unfavorable intention. In favorable behavioral intention if the customer interacts with service provided shows commend service provider to other consumer, increase their purchasing or ready to pay additional cost from benefit of income, and shows behavior that customer stay to create relation with service provider, it is considered favorable attitude. Definition of favorable behavioral intention is positive relation and significant between customer perception about quality service and customer desire to recommended a business that serve to other.

The result of the research showed that was effect of customer value to the behavior intentions, this result compatible with the research from Grisaffe and Kumar (1998) also Petrick (2002). From research result showed that there was relation between customer value and behavior intentions.

\section{The Effect of Trust to the Behavioral Intentions}

The effect of trust variable to the behavior intentions was positive. This meant that the increase of trust is followed by the improvement of behavior intentions with assumptions other factors that affect the trust size is considered constant. The research result showed that trust significant affect to the behavior intentions, this result compatible with research of Doney and Cannon (1997) prove that the role of trust in behavior intentions of purchasing back to the future. Besides that, the research from Ruben Chumpitaz Caceres and Nicholas G. Paparoidamis (2005) in the research argue that customer trust affect to the customer loyalty. So, the company try to make trust to the customer mind in order that the customer sustainable use their product.

According to Zeithaml (2003) one of dimensions from behavioral intention is loyalty to company (Loyalty), is a situation where customer repurchase regularly, cannot be influenced by competitors to move and refer to others. The research result showed that the effect of trust to the behavior intentions, this research could compatible with research of Wang, Ngamsiriudom and Chia-Hung (2015). From the result research showed that the relationship of trust and behavior intentions significantly positive.

\section{Conclusion and Suggestion}

Based on the research findings in the previous chapter, will be clarified in the conclusion and suggestion as follows:

\section{A. Conclusion}

Based on the problem statements in this research, the research hypotheses and result of data analysis and findings of result analysis, it can be concluded as follows:

1. Perceived image effects to the customer value. So, when the hotel increased perceived image directly will increase customer value. 
2. Customer experience effects to the customer value. So, when the hotel increase customer experience directly will increase customer value.

3. Perceived image effects to the trust. So that, when the hotel increase perceive image directly it will increase trust.

4. Customer experience effects to trust. So the hotel increase the customer experience directly will increase trust.

5. Perceived image effects to the behavior intention. So that, when the hotel increase perceived image directly, it will increase behavior intention.

6. The customer experience effects to the behavior intention. So the hotel increase customer experience directly, it will be increase behavior intention.

7. Customer value effects to the behavior intention. So when the hotel increases the customer value directly will increase behavior intention.

8. Trust effect to the behavior intention. So when the hotel increases trust directly will increase the behavior intention.

\section{B. Suggestion}

Based on the conclusion, research implication and scope of the research that has explained in the previous chapter, some suggestion from this research as follows:

1. In increasing perceived image to the customer value, the hotel needs to make efforts or strategy by increasing Advertising, Public relation, Physical Image, and Actual Experience so that the impression obtained in accordance with the knowledge and someone experience about hotel.

2. In increasing customer value through customer experience, the hotel needs to make efforts that more interaction to the customer through Accessibility, Competence, Customer Recognition, Helpfulness, Personalization, Problem Solving, Promise Fulfillment and Value For Time.

3. In increasing perceived image to the customer trust, the hotel needs to make efforts through Advertising, Public Relation, Physical Image, and Actual Experience, so that can reassuring hope and customer desire to reuse hotel service. Other side, the hotel should monitor and survey customer satisfaction.

4. In increasing trust through customer experience, so the hotel is better to priority Accessibility, Competence, Customer Recognition, helpfulness, Personalization, Problem Solving, promise Fulfillment and Value for Time. Hotel readiness in helping customer difficulties, resolve customer complaints appropriately, give clear information based on customer' need create positive experience that experienced by customer to establish trust of customer.

5. In increasing perceived image to the behavior intention, the hotel should give best impression to make innovation to the product service that offered and establish a good image in the minds of customer, so, the customer interested in repeated visits and tell others about the service that they feel.

6. In increasing behavior intention through customer experience, the hotel should increase services performance especially the implementation of delivery service through personalized guest service based on guests' need, knowing the purpose of guest's stay by write it in note system lightspeed that used. Therefore, facility, and service provide will be tailored to the customer. Therefore, the customer will reuse the service of the hotel based on the service experience that they received.

7. In increasing behavior intention through customer value, the hotel should consider the suitability of consumer perceived value hotel between the price of services and products with quality hotel services and products. Maintain conformity can be done with recall the customers that have reserve whether they are satisfied or dissatisfied with the services that have been used, may use the website, suggestion box, or customer service. Hotel can make promotion about hotel product then give update information to the company/ hotel official website. Hotel also can make product that less interested in an upgrade based on customer needs.

8. In increasing the behavior intention through customer experience, the hotel should always pay attention and keep the trust of customer who are committed to use the product or service that hotel's offered. Fulfill a promise in writing or not to their customers is essential, a company can promote the provision appointments, then improve external communications with their customers so that the customers themselves can become marketing service because they could recommend to others to use the service of the hotel.

[1]. Albrecht, K. 1994. The Northbound Train. New York: Amacom

[2]. Anderson, E.W. and Sullivan, M.W. 1993, The Antecedents and Consequences of Customer Satisfaction for Firms, Marketing Science, Vol. 12, Spring, pp. 125-43.

[3]. Andreassen Tor Wallin and Lindestad Bodil. 1997. Customer loyalty and complex services: The impact of corporate image on quality, customer satisfaction and ees of service expertise, International Journal of Service Industry Management, Vol.9, No. 1, pp $7-23$. 
[4]. Baker, J., Levy, M. \& Grewal, D. 1992. An Experimental Approach to Making Retail Store Environment Decisions. Journal of Retailing, 68 (4), 445-460.

[5]. Berry, L. and Yadav, M. 1996, "Capture and Communicate Value in the Pricing of Services", Management Review, Summer, pp. 41-51.

[6]. Bhattacharya, P. Evinney, H. \& Pillutla, A. 1998. Communication and Innovation. The Case of Technology Banking System. An International Journal of Communica-tion. Wales: MCB UP Limited.

[7]. Bigne, J. E., Mattila, A. S., \& Andreu, L. 2008. The Impact of Experiential Consumption Cognitions and Emotions on Behavioral Intentions. Journal of Services Marketing, 22 (4), 303-315.

[8]. Bolton, R. N., Kannan, P. K., \& Bramlett, M. D. 2000. Implications of Loyalty Program Membership and Service Experiences for Customer Retention and Value. Journal of the Academy of Marketing Science, 28 (1), 95-108.

[9]. Bontis, Nick., and Lorne D. Booker. 2007. The mediating effect of organizational reputation on customer loyalty and service recommendation in banking industry. Management Decision, Vol. 45, No. 9 p. 1426-1445

[10]. Buchari Alma. 2005. Kewirausahaan Untuk Mahsiswa Dan Umum. PT. ALFABETA, Bandung

[11]. Butz, Howard E and Leonard D. Goodstein. 1996. Measuring Customer Value : Gaining the Strategic Adventage, Organizational Dynamic, 24 (Winter): $63-77$

[12]. Chang, H. H., \& Chen, S. W. 2008. The Impact of Customer Interface Quality, Satisfaction and Switching Costs on E-Loyalty: Internet Experience as a Moderator. Computers in Human Behavior, 1016 (10).

[13]. Chaudhuri, Arjun. and Morris Holbrook, B. 2001, "The chain of effects from brand trust and brand affect to brand performance: the role of brand loyalty," Journal of Marketing, Vol 65, April, p. 81-93.

[14]. Chumpitaz, Ruben \& Paparoidamis, Nicholas. 2005. Service quality, relationship satisfaction, trust, commitment and business-tobusiness loyalty". Journal of Commerce

[15]. Doney, P.M., and Cannon, J.P., 1997, “An Examination of The Nature of Trust in Buyer - Seller Relationship, "Journal of Marketing" April, pp. 35-51.

[16]. Engel, James F, et.al., 1995, Consumen Behavior, Alih Bahasa: Budiyanto, Jilid 1 dan 2, Bina Rupa Aksara, Jakarta

[17]. Fornell, C Johnson, MD Anderson, EW Cha, and Bryant BE, 1996, "The American Customer Satisfaction Index: Nature, Purpose, and Findings," Journal of Marketing, Vol.60

[18]. Fornell, C., 1992, “A National Customer Satisfaction Barometer: The Swedish Experience, Journal of Marketing, Vol. 60, pp. 7-17

[19]. Fornell, C., et al. 1996. "The American Customer Satifaction Index: Nature, Purpose, and FIndings". Journal of Marketing 60, 7-18

[20]. Gale, BT. dan Wood, RC, 1994, Managing Customer Value: Creating Quality and Service That Customer Can See, Free Press., New York

[21]. Ganesan, B.L. 1994. Marketing Services, Enlington Avenue East, New York: Mac-Millan Inc.

[22]. Gefen, D., 2002. Customer Loyalty in E-Commerce, Journal of the Association for Information Systems, 3:27-51.

[23]. Gentile, C., Spiller, N., \& Noci, G. 2007. How to Sustain the Customer Experience: An Overview of Experience Components that Co-create Value with the Customer. European Management Journal, 25(5), 395-410.

[24]. Gerson, R. F. 2001. Commentary. The psychological side of performance improvement. Perf. Improv., 40: 7-11. doi: 10.1002/pfi.4140400504.

[25]. Griffin , Jill. 2005. Customer Loyalty, Menumbuhkan dan Mempertahankan Kesetiaan. Pelanggan. Penerbit : Erlangga, Jakarta

[26]. Gronroos, C. 2000, Service Management and Marketing: A Customer Relationship Management Approach, 2"" edition, Chichester: John Willey \& Sons, Ltd.

[27]. Hollyoake, M. 2009. Customer Experience in B2B Environment.Retrieved September 18, 2012, from www.springboardcs.com/articles/ uploads/CxP_IN_B2B.pdf

[28]. http://www.tempo.co/read/news/2014/03/25/058565168/31-Hotel-Dibuka- di -Makassar-Tahun-Ini

[29]. Hunt, K. 1977. Conceptualization and Measurement of Consumer Satisfaction and Dissa tisfaction (Hunt ed.). Cambridge, MA: Marketing Science Institute.

[30]. Huriyati, R., 2005. Bauran Pemasaran dan Loyalitas Konsumen: Fokus pada Konsumen Kartu Kredit Perbankan, Cetakan Pertama. Bandung: Alfabeta

[31]. Istijanto. 2009. Aplikasi Praktis Riset Pemasaran. Jakarta: Gramedia Pustaka Utama.

[32]. Kandampully dan Suhartanto. 2000. Customer Loyalty in the Hotel Industry: The Role of Customer Satisfaction and Image. International Journal of Contemporary Hospitality Management 12/6:346-351

[33]. Kim, D. J., Ferrin, D. L., dan Rao, H. R., 2003. Antecedents of Consumer Trust in B-to-C Electronic Commerce, Proceedings of Ninth Americas Conference on Information Systems, pp. 157-167.

[34]. Kotler, Philip and Gary Amstrong. 2001. Dasar-dasar Pemasaran. Edisi Kesembilan: Jilid Satu. Jakarta : PT Indeks

[35]. Kotler, Philip. 2000. Manajemen Pemasaran, Edisi Milenium, Jilid 1. Penerjemah PT. Prenhallindo, Jakarta.

[36]. Laohasirichaikul Bunthuwun, Chaipoopirutana Sirion, Combs Howard. 2010. Efeective Custumer Relationship Management of Health Care : A Study of Perception of Service Quality, Corporate Image, Satisfaction, and Loyalty of Thai Outpatients of Private Hospitals in Thailand. ABBS.

[37]. Lau,G.T and S.H Lee. 1999. Customer Trust in Brand Loyalty, Journal of Market Focused management. No. 4, p.341-370

[38]. Lemke, F., Clark, M., \&Wilson, H. 2006. What Makes a Great Customer Experience. Cranfield Customer Management Forum.

[39]. Mano, H., \& Oliver, R. L. 1997. Assessing the Dimensionality and Structure of the Consumption Experience: Evaluation, Feeling, and Satisfaction. Journal of Consumer Research, 20 (3), 451-466.

[40]. Mayer, F. Davis, A. \& Schoorman, K. 1995. The Evolution and Use of Communication and Information Technology in Marketing, Oxford: Butterworth Heinemann.

[41]. Mayer, R.C., Davis, J. H., dan Schoorman, F. D., 1995. An Integratif Model of Organizational Trust, Academy of Management Review, 30 (3): 709-734.

[42]. Meyer, Christopher and Andre Schwager. 2007, Understanding Customer Experience, Harvard Business Review No. R0702G, hal. $1-13$.

[43]. Monroe, K.B., 1990. Pricing, Making Profitable Decissions, Second Edition, McGraw-Hill, New York

[44]. Morgan, M.J. \& Hunt, R. 1994. Pioneering and Market Share: Is Entry Time Endoge-neous and does it Matter. Journal of Marketing XXV:97.

[45]. Mowen, John, C., dan Minor, M., 2002, Perilaku Konsumen Jilid 1, Edisi Kelima (terjemahan), Erlangga, Jakarta

[46]. Naumann, Earl. 1995. Creating Customer Value : The Path To Sustainable Advantage. Ohio: Thompson Executive Press

[47]. Oliver, Richard L. 1999, Whence Consumer Loyalty, Journal of Marketing, 63 (Special Issue), 33-44.

[48]. Olson. 2000. Prilaku Konsumen dan Strategi Pemasaran. Jakarta: Alih Bahasa Damos Sihombing, Ed.4

[49]. Peppers, D., and Rogers, M. 2004. Managing Customer Relationships: A Strategic Framework, New York: John Wiley 
[50]. Peppers, D., and Rogers, M. 2004. Managing Customer Relationships: A Strategic Framework, New York: John Wiley

[51]. Peter, J. Paul dan Jerry C Olson. 2000. Consumer behavior: Perilaku Konsumen Dan Strategi Pemasaran Jilid 1. Edisi Keempat. Jakarta: Erlangga.

[52]. Ravald, A \& Christian, G., 1996. "The value concept and relationship marketing”, European Journal of Marketing, Vol.30

[53]. Rousseau, D.M., S.B. Sitkin, R.S. Burt, and C. Camerer. 1998. Not So Different After All: A Cross-Discipline View of Trust. Academy of Management Review 23:393-404

[54]. Schiffman \& Kanuk. 2004. Perilaku Konsumen (edisi 7). Jakarta : Prentice Hal

[55]. Schmitt. 1999. Experiential Marketing, How to Get Customer to Sense, Feel, Think, Act, Relate, to Your Company and Brands. New York : The Free Press

[56]. Seddon, J., \& Sant, R. 2007. Increasing Business Value through Improved Customer Experiences. EPerspectives, December. Retrieved October 22, 2014 from http://www.millwardbrown.com.

[57]. Simon et al., 2005. "Customer Relationship Dynamics: Service Quality and Customer Loyalty in the Context of Varying Levels of Customer Expertise and Switching Costs", Academy of Marketing Science, Vol.33, No.2, pp 169- 183

[58]. Slater and Narver, 1994, ” Does Competitive Moderate the Orientation Performance Relationship?", Journal of Marketing, 58(1), pp. 46-55.

[59]. Sugiyono, 2008. Metode Penelitian Bisnis.Cetakan keduabelas 2008. Bandung; Alfabeta.

[60]. Suharsimi,A, 2010. Prosedur Penelitian Suatu Pendekatan Praktik. Jakarta : Rineka Cipta.

[61]. Suryabrata,S, 2003. Metodologi Penelitian.Jakarta: Raja Grafindo Persada.

[62]. Sutanto, J.E. 2009. Dimension Quality of Service Influence Satisfaction in the Hotel ( A Case study an examination of the transaction Model in Service Industry). ISSN: 1978-774X Proceeding, International Seminar on Industrial Engineering and Management.

[63]. Tang, Weiwei. 2007. Impact of Corporate image and Corporate Reputation on Customer Loyalty : A Review. Management Science and Engineering.

[64]. Tax, Stephen, Stephen Brown, and Murali Chandrashekaran, 1998. "Customer Evaluations of Service Complaint Experiences: Implications for Relationship Marketing," Journal of Marketing, Vol 60, pp. 60-76.

[65]. Tjiptono, F. 2008. Pemasaran Jasa. Malang: Bayu Media Publishing.

[66]. Tjiptono. F, 2005. Pemasaran Jasa, Edisi pertama, Bayu Media Publishing, Malang.

[67]. Treacy, Michael and Fred Wiersema. 1995; The Discipline of Market Leader. New York: The Free Press

[68]. Tse. O.K., dan P.e. Wilton. 1988. "Models of Consumer Satisfaction Formation: AnExtention". Journal of Marketing Research. Vol. 25. May

[69]. Tu, Y. T., Wang, C. M., \& Chang, H. C. 2012. Corporate Brand Image and Customer Satisfaction on Loyalty: An Empirical Study of Starbucks Coffee in Taiwan. Journal of Social and Development Sciences, 3 (1), 24-32.

[70]. Venkat, R. 2007. Impact of Customer Experience on Satisfaction, Brand Image and Loyalty: A Study in a Business-to-Business Context. Journal of Marketing, 3.

[71]. Wakefield, K. L. \& Blodgett, J. G. 1996. The Effect of the Servicescape on Consumers' Behavioral Intentions in Leisure Service Settings. Journal of Services Marketing, 10 (6), 45-61.

[72]. Woodruff, Robert B. 1997. Customer Value : The Next Source for Competitive Advantage, Journal of the Academy of Marketing Science, Vol. 25, No. 2, $139-153$

[73]. Yamit, Zulian. 2003. Manajemen Produksi dan Operasi. Second edition. Ekonosia. Fakultas Ekonomi UII, Yogyakarta

[74]. Yang, Z \& Peterson, R.T., 2004. Customer Perceived Value, Satisfaction, and Loyalty: The Role of Switching Costs, Psychology and Marketing, Vol.21, pp 799-822

[75]. Yousafzai, S. Y., Pallister, J. G., dan Foxall, G. R., 2003. A Proposed Model of ETrust for Electronic Banking, Technovation, 23: 847-860.

[76]. Zeithaml, V.A, Berry, L.L, Parasuraman, A. 1996, The behavioral consequences of service quality, Journal of Marketing, Vol. 60 pp.31-46. 